\title{
Correction to: A trans fatty acid substitute enhanced development of liver proliferative lesions induced in mice by feeding a cholinedeficient, methionine-lowered, L-amino acid-defined, high-fat diet.
}

Noriko Suzuki-Kemuriyama', Akari Abe ${ }^{2}$, Kinuko Uno ${ }^{3}$, Shuji Ogawa ${ }^{3}$, Atsushi Watanabe², Ryuhei Sano², Megumi Yuki ${ }^{2}$, Katsuhiro Miyajima ${ }^{1,2}$ and Dai Nakae ${ }^{1,2^{*}}$

Correction to: Lipids Health Dis 19, 251 (2020). https://doi.org/10.1186/s12944-020-01423-3

Following publication of the original article [1], the authors noticed that the first name of one of the coauthors Mx. Uno was wrongly printed. The said author name needs to be corrected from "Kiniko Uno" to "Kinuko Uno". The original article has been updated.

\section{Author details}

'Department of Nutritional Science and Food Safety, Faculty of Applied Bioscience, Tokyo University of Agriculture, 1-1-1, Sakuragaoka, Setagaya, Tokyo 156-8502, Japan. ${ }^{2}$ Department of Nutritional Science and Food Safety, Graduate School of Applied Bioscience, Tokyo University of Agriculture, 1-1-1 Sakuragaoka, Setagaya, Tokyo 156-8502, Japan. ${ }^{3}$ Department of Food and Nutritional Science, Graduate School of Applied Bioscience, Tokyo University of Agriculture, 1-1-1, Sakuragaoka, Setagaya, Tokyo 156-8502, Japan.
Published online: 07 January 2022

\section{Reference}

1. Suzuki-Kemuriyama N, Abe A, Uno K, Ogawa S, Watanabe A, Sano R, et al. A trans fatty acid substitute enhanced development of liver proliferative lesions induced in mice by feeding a choline-deficient, methionine-lowered, L-amino acid-defined, high-fat diet. Lipids Health Dis. 2020;19(1):251. https:// doi.org/10.1186/s12944-020-01423-3.
The original article can be found online at https://doi.org/10.1186/s12944020-01423-3.

* Correspondence: agalennde.dai@nifty.com

${ }^{1}$ Department of Nutritional Science and Food Safety, Faculty of Applied Bioscience, Tokyo University of Agriculture, 1-1-1, Sakuragaoka, Setagaya, Tokyo 156-8502, Japan

${ }^{2}$ Department of Nutritional Science and Food Safety, Graduate School of Applied Bioscience, Tokyo University of Agriculture, 1-1-1 Sakuragaoka, Setagaya, Tokyo 156-8502, Japan

Full list of author information is available at the end of the article

(c) The Author(s). 2021 Open Access This article is licensed under a Creative Commons Attribution 4.0 International License, which permits use, sharing, adaptation, distribution and reproduction in any medium or format, as long as you give appropriate credit to the original author(s) and the source, provide a link to the Creative Commons licence, and indicate if changes were made. The images or other third party material in this article are included in the article's Creative Commons licence, unless indicated otherwise in a credit line to the material. If material is not included in the article's Creative Commons licence and your intended use is not permitted by statutory regulation or exceeds the permitted use, you will need to obtain permission directly from the copyright holder. To view a copy of this licence, visit http://creativecommons.org/licenses/by/4.0/ The Creative Commons Public Domain Dedication waiver (http://creativecommons.org/publicdomain/zero/1.0/) applies to the data made available in this article, unless otherwise stated in a credit line to the data. 